\title{
THE SAN FERNANDO EARTHQUAKE AND PUBLIC SCHOOL SAFETY
}

\author{
By D. E. Hudson ANd D. K. JePhCott
}

\begin{abstract}
The San Fernando earthquake was an unusually valuable test of school safety because: (1) there were several hundred schools having structures of all types in the heavily shaken area, including 10 schools within 5 miles of the epicenter; (2) the severity of ground motion is believed to have been near the maximum to be expected for an earthquake of any size-a number of campuses were subjected to major ground cracking and deformation; (3) since there were many instruments in the area, the details of the earthquake ground motion are better known than for any other earthquake. On some campuses, pre-Field Act buildings, renovated pre-Field Act buildings, and new buildings existed side by side, and direct comparisons show the efficacy of the Field Act and the associated plan check and field inspection procedures in reducing the earthquake hazard to an acceptably low level. No structural failures, that would have been likely to cause serious injury or death if the buildings had been normally occupied at the time of the earthquake, occurred in any buildings built to current standards. There were, however, some failures of nonstructural elements that could have resulted in a hazardous situation and demonstrate the need for upgrading requirements in this area of building construction.
\end{abstract}

\section{INTRODUCTION}

Although the San Fernando earthquake was not a major seismic event from the standpoint of size, several special circumstances make it of great importance both for seismology and for earthquake engineering. (1) The earthquake occurred on the edge of a highly urbanized area containing many modern structures, such as electric power stations, dams, reservoirs, hospitals, schools, industrial structures, and high-rise buildings. Many of these structures had been designed for earthquake resistance, and this earthquake provided by far the most extensive test to date of the soundness of modern theories of earthquake lateral force design. (2) The event was well instrumented from both the seismological and the earthquake engineering point of view. The ready availability in the area of many highly trained geophysicists and of much modern equipment made it possible to obtain unusually complete and accurate aftershock data and information on tectonic movements. The area was covered by an unusually dense network of strong-motion accelerographs which produced an unprecedented picture of the distribution of strong ground shaking throughout the epicentral region and which provided quantitative measurements of high accuracy of structural input motions. The existence of many accelerographs in the upper floors of buildings also provided much information on building response at force levels much higher than had ever been obtained by artificial tests of full-scale structures. (3) Because of the nature of the faulting and the characteristics of the local geological setting, the local severity of ground shaking attained levels which are believed to be close to the upper bounds to be expected for tectonic earthquake 
ground motions. (4) Details of the geological features of the epicentral region were unusually well known. The region had been explored in great detail because of its economic importance, its proximity to a major metropolitan area, and the inherent interest of its complex geology. The area had been for many years a favorite field site for generations of geological students from three major universities and had been extensively examined in the course of oil company explorations and aqueduct siting studies. (5) Because of the large number of public school buildings distributed over the epicentral region and since these school buildings had been built over a period of many years, in some cases pre-dating earthquake-resistant design code provisions, the event has provided a unique opportunity to study the effectiveness of current school design and construction procedures in reducing the earthquake hazard.

Because of the special importance of the school safety problem, a decision was made immediately after the earthquake to prepare a comprehensive report on the performance of typical public school buildings. The present paper summarizes a portion of this report, with special reference to the seismological setting of the event (Jephcott and Hudson, 1974).

Figure 1 shows the general setting and the distribution of schools in the heavily shaken region. There were 10 public schools located within 5 miles of the epicenter, 59 within 10 miles, 160 within 15 miles, and 416 within 25 miles, a distance at which some major structural damage occurred to some old substandard school buildings. Although 17 different school districts were involved, most of the schools shown are part of the Los Angeles Unified School District, which consists of some 9,000 separate structures with an assessed evaluation of one billion dollars. Of this group, the total cost of earthquake damage repair to post-1933 school buildings constructed under the Field Act was about $\$ 2,700,000$, just a fraction of 1 per cent of the assessed evaluation. This damage was mostly to non-structural elements, but included some minor nonhazardous structural damage. The only dangerous collapses which occurred were to old, pre-Field Act structures.

\section{THE EARTHQUAKE}

The earthquake occurred on February 9, 1971, at 0600 PST with no foreshock activity of any kind noted. The reported preliminary epicentral location was $34^{\circ} 24^{\prime} \mathrm{N}, 118^{\circ}$ 23.7' $\mathrm{W}$, and the depth of focus, $13 \mathrm{~km}$ (Allen et al., 1971). This preliminary hypocentral location has been modified by varying amounts in later publications as more detailed studies of the event proceeded (Hanks, 1974). The remaining uncertainties as to the exact location of the initial point of energy release are not of significance for an explanation of the engineering features of the earthquake.

The maximum Modified Mercalli intensity in the epicentral region was assessed at XI (Scott, 1971). The Gutenberg-Richter magnitude $\left(M_{L}\right)$ has been established as 6.4 (Allen et al., in press), revised from a preliminary determination of 6.6 (Allen et al., 1971).

\section{SOURCE MeChanism}

An understanding of the nature of the faulting involved in the earthquake is of special importance in explaining the very strong ground deformation and shaking which occurred throughout a region containing many school buildings. Because of the special conditions at the source, the ground motions were considerably more severe than might have been expected for a California earthquake of this magnitude. It seems likely that 
the strength of the local ground shaking in the epicentral area was near the upper limits to be expected for an earthquake of any size, and this gives the schoolhouse test an additional special significance.

The general extent and pattern of the epicentral region is revealed by the aftershock pattern of Figure 2 (Allen et al., 1971). Also shown in Figure 2 are a number of the schools studied in the present report. Detailed studies of the earthquake fault mechanism

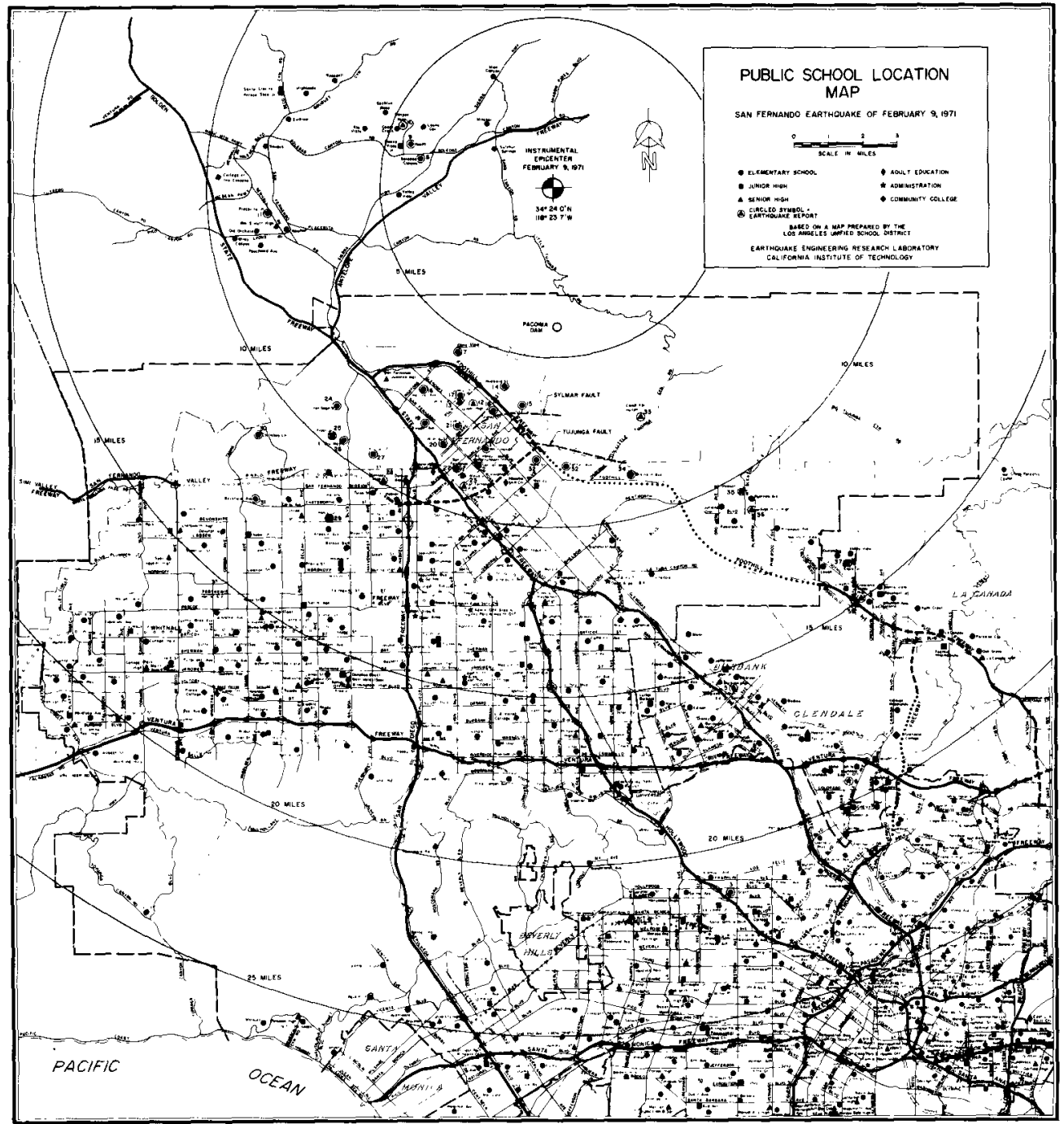

FIG. 1. Location of public schools in the epicentral region.

show that the fault motions propagated southward away from the epicenter, and it is clear that the schools shown are located very near to regions of very large energy release during the rupture process.

Additional features of the mechanism of faulting are shown in the vertical crosssection of Figure 3 along with the locations of several of the schools studied. The shape and angle of the fault rupture surface cannot be accurately determined because of uncertainties in the location of the hypocenter, but the main features of the overthrust 
fault are sufficiently established to explain the main characteristics of ground shaking in the epicentral region. Detailed studies of fault dislocation models have shown that the energy release was not uniform over the rupture surface, but was largest near the hypocenter and near the surface (Trifunac, 1974). It is of great importance to note that many of the school buildings of the present study were thus located considerably closer to regions of very strong seismic energy release than might be implied by the epicentral distance and the magnitude of the earthquake. Figure 4 shows additional details of the location of schools directly in areas of severe ground distortion (Bonilla et al., 1971).

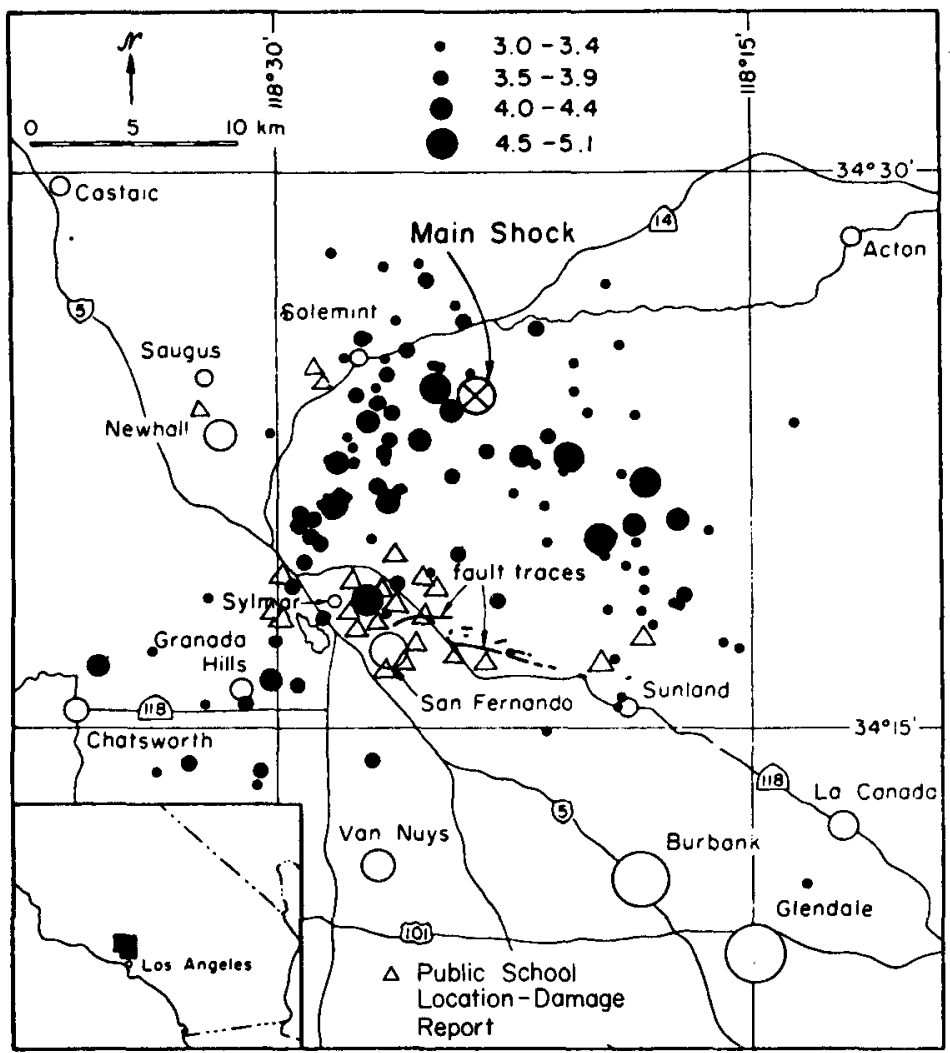

FIG. 2. Aftershock distribution map, showing location of selected public schools.

\section{Patterns of Ground Shaking}

The Los Angeles region was unusually well covered by strong-motion accelerograph instrumentation, mainly as a consequence of the adoption by the City of Los Angeles in 1965 of a building code provision requiring accelerographs in many buildings. The distribution of ground accelerations over the whole Los Angeles region was thus accurately measured and was found to present a complicated pattern. It is, of course, well known that values of peak acceleration are not to be correlated directly with structural damage. For a specific earthquake and region, however, they do describe in a rough way the general pattern of distribution of ground shaking. Figure 5 shows the magnitudes of the peak ground acceleration of the larger horizontal component for a number of selected stations (Hudson and Udwadia, 1973). It will be noted that there are many interesting nonuniformities in the pattern of ground shaking. For example, there 


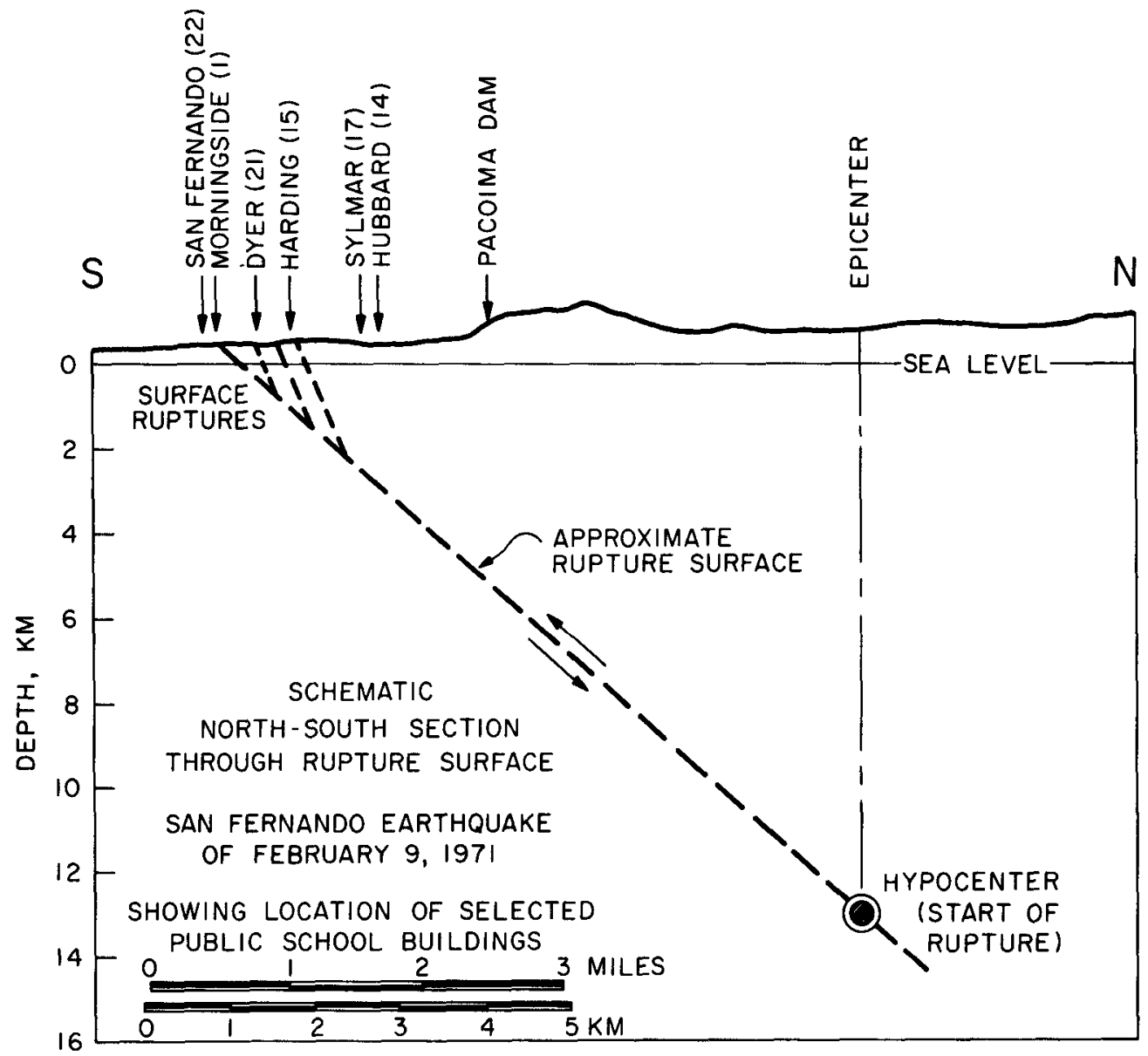

FIG. 3. Schematic vertical section through fault, with locations of selected schools.

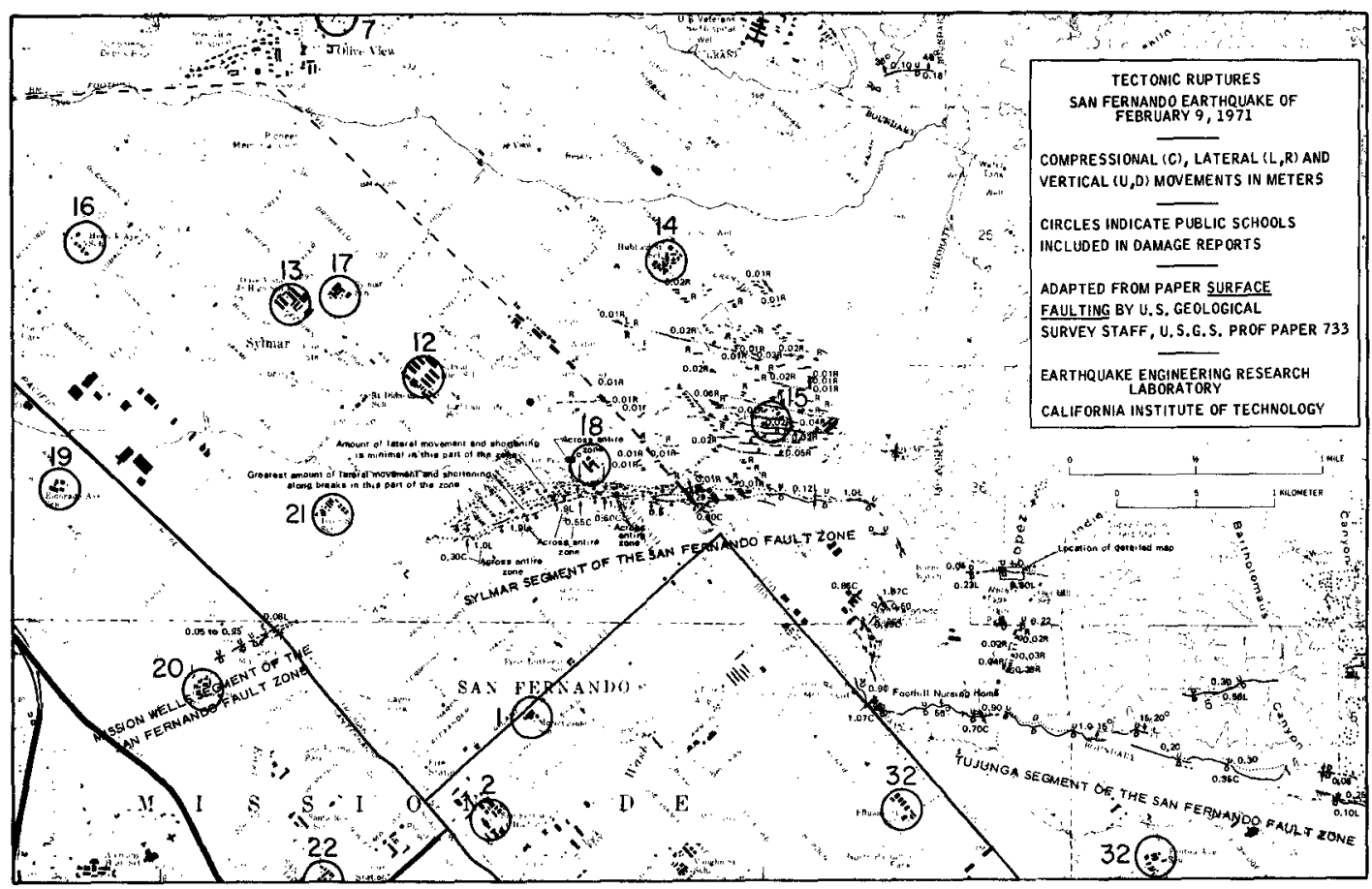

FIG. 4. Tectonic ruptures and school locations (Bonilla, 1971). 


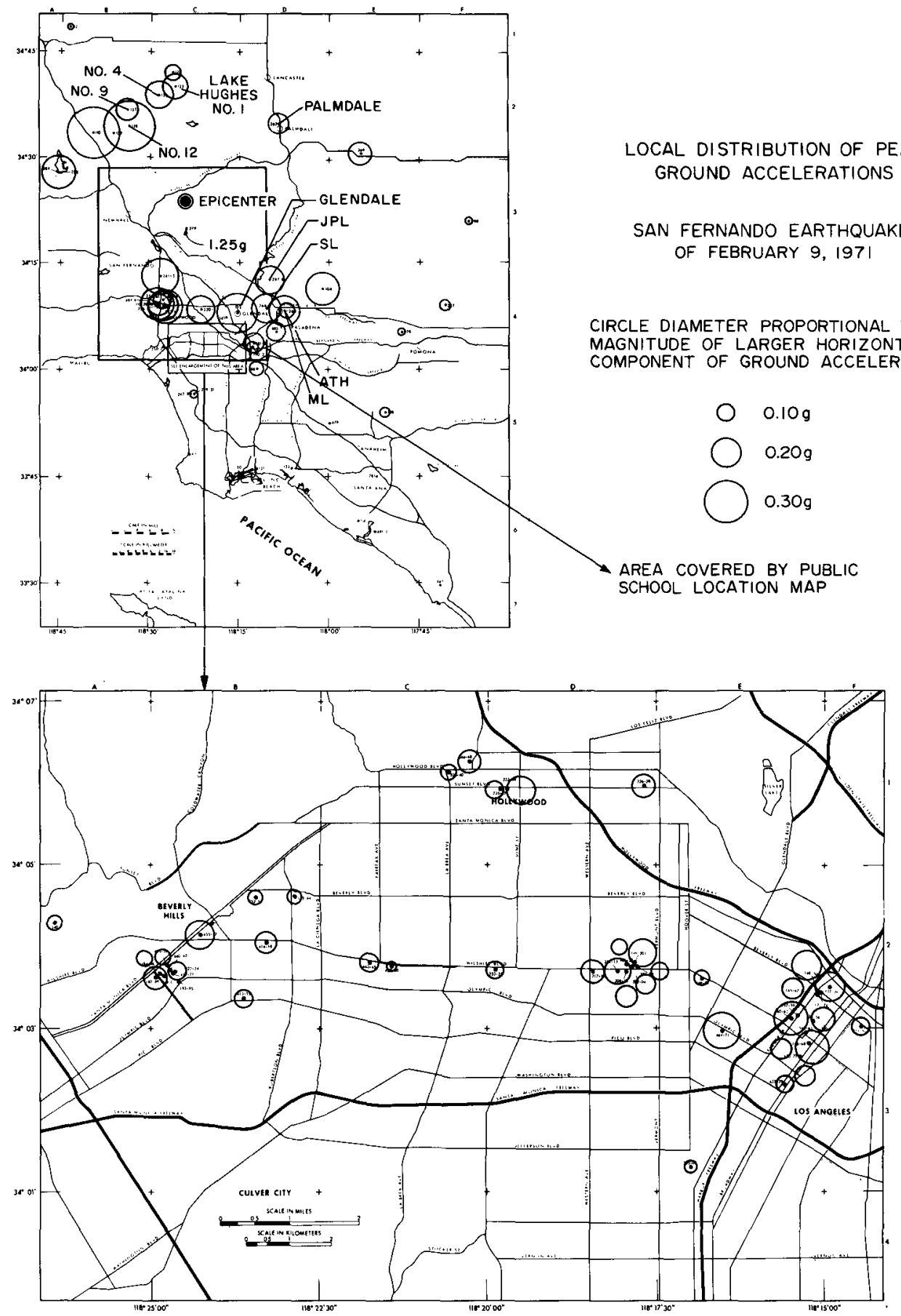

FIG. 5. Distribution of measured ground accelerations. 
are unusually large motions in the Lake Hughes region, in Glendale, and in the downtown Los Angeles area along the Harbor Freeway. Also shown in Figure 5 is the rectangular area covered by the Public School Location Map of Figure 1, which is seen to occupy a central spot with respect to the area involved in the earthquake. The complicated distribution patterns show why it is difficult to estimate closely the ground motions of a particular school site even if an accelerograph is located close by. There are significant differences between the ground motions of sites only a fraction of a mile apart. These differences are caused by variations in the propagation paths of the seismic waves, by surface and subsurface topography, and by details of local geological and soil conditions (Hudson, 1972). In the present state of knowledge, it is not to be expected that the motions at the various sites can be either quantitatively explained or predicted. Should another earthquake occur in a different or even the same location, it seems likely that a similarly complicated pattern of ground-motion distribution would be obtained, but one which might be different from the distribution for the San Fernando earthquake.

\section{Limits OF GRound SHAKING}

Considering the basic fracture mechanisms involved in tectonic earthquakes and the ultimate strength properties of crustal rocks, it is probable that there is an upper bound for the severity of ground shaking resulting from tectonic earthquakes. This upper bound cannot be expressed simply in terms of one parameter, such as peak ground acceleration, because such additional factors as frequency of the dominant components are also of significance. In addition, the damaging potential to structures of these ground motions will depend upon such other factors as the time duration of strong shaking.

Considering, first, only the peak amplitudes of ground shaking, it appears that these may be as severe for a moderate earthquake as for a large one. An earthquake becomes large by involving a large area in the energy release process. In the 1964 Alaska earthquake, for example, fault rupture extended over hundreds of miles. This inevitably means, however, that any one particular point will be located at a large distance from some of the regions of energy release, and it will be only those relatively small fault areas nearby which will be responsible for the largest ground motions. In other words, a large tectonic earthquake is in effect a whole series of small earthquakes distributed spatially and in time over a large area. A particular point will feel the nearest shocks of the series strongly, but will be less influenced by the more distant portions of the event. It is also clear from this general picture that the motions from the large earthquake will persist for a longer time, although at varying amplitude levels.

With the above thoughts in mind, it can be concluded that the ground shaking along the southern border of the epicentral region of the San Fernando earthquake was about as large as would be expected for a much larger earthquake. In the larger earthquake a greater area would be subjected to heavy ground shaking, but the shaking at any one point would not be significantly bigger. The time durations of the strongest ground shaking would also be about the same for the small and large earthquake, but the total time of large ground motions would be considerably greater for the bigger earthquake.

The above ideas are further substantiated by studies of two very large earthquakesthe San Francisco $1906(M=8.3)$ and the Alaskan earthquake of $1964(M=8.5)$. Although accurate measurements are not available from the 1906 earthquake to compare with the San Fernando accelerograms, there is no evidence to suggest that there were any more intense local ground motions in 1906 than in San Fernando. Although a different intensity scale was used to rate the San Francisco event, a study of numerous photographs does not suggest that equivalent Modified Mercalli intensities as great as 
those reported for San Fernando were anywhere involved (Lawson, 1908). Considering San Francisco, it was concluded by Richter that the highest intensity in 1906 "would rate as IX or slightly over" on the Modified Mercalli scale (Richter, 1958). There may have been some higher intensities outside the San Francisco area, but this is a matter for some speculation.

A similar situation exists for the Alaskan earthquake of 1964. The maximum reported Modified Mercalli intensity for the Alaskan earthquake did not exceed XI (Von Hake

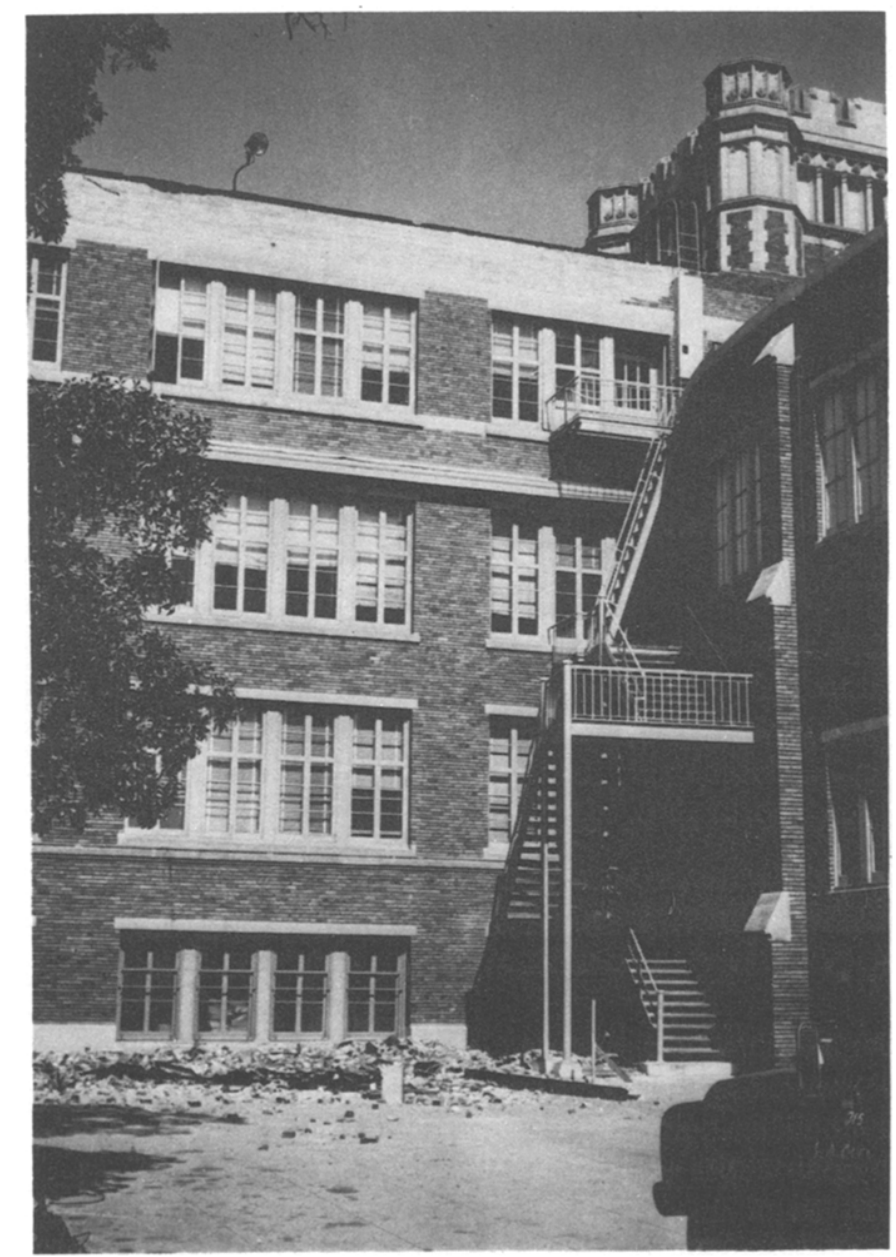

Fig. 6. Masonry wall damage at Los Angeles High School.

and Cloud, 1966; Hudson and Cloud, 1973). This assessment was made by essentially the same group of investigators who rated the San Fernando earthquake as XI. A general consensus of earthquake engineers who examined in detail structural failures in both Alaska and San Fernando is that local ground shaking was at least as great in San Fernando as in Alaska, and was probably somewhat greater (Housner, 1973).

It must be remembered that the longer duration of strong ground shaking to be expected in great earthquakes such as 1906 and 1964 would make these earthquakes more damaging events for some structures. It is clear, however, that the magnitude scale alone does not correlate well with general destructive effects. 


\section{COMPaRisons With THE LONG Beach EARTHQuAKe}

The Long Beach earthquake of 1933 was a major event for the development of earthquake-resistant design codes and in particular for the Field Act establishing special measures for providing earthquake safety of schools. The very severe damage to practically all public school buildings shocked the public into an awareness of the earthquake hazard which finally resulted in effective action.

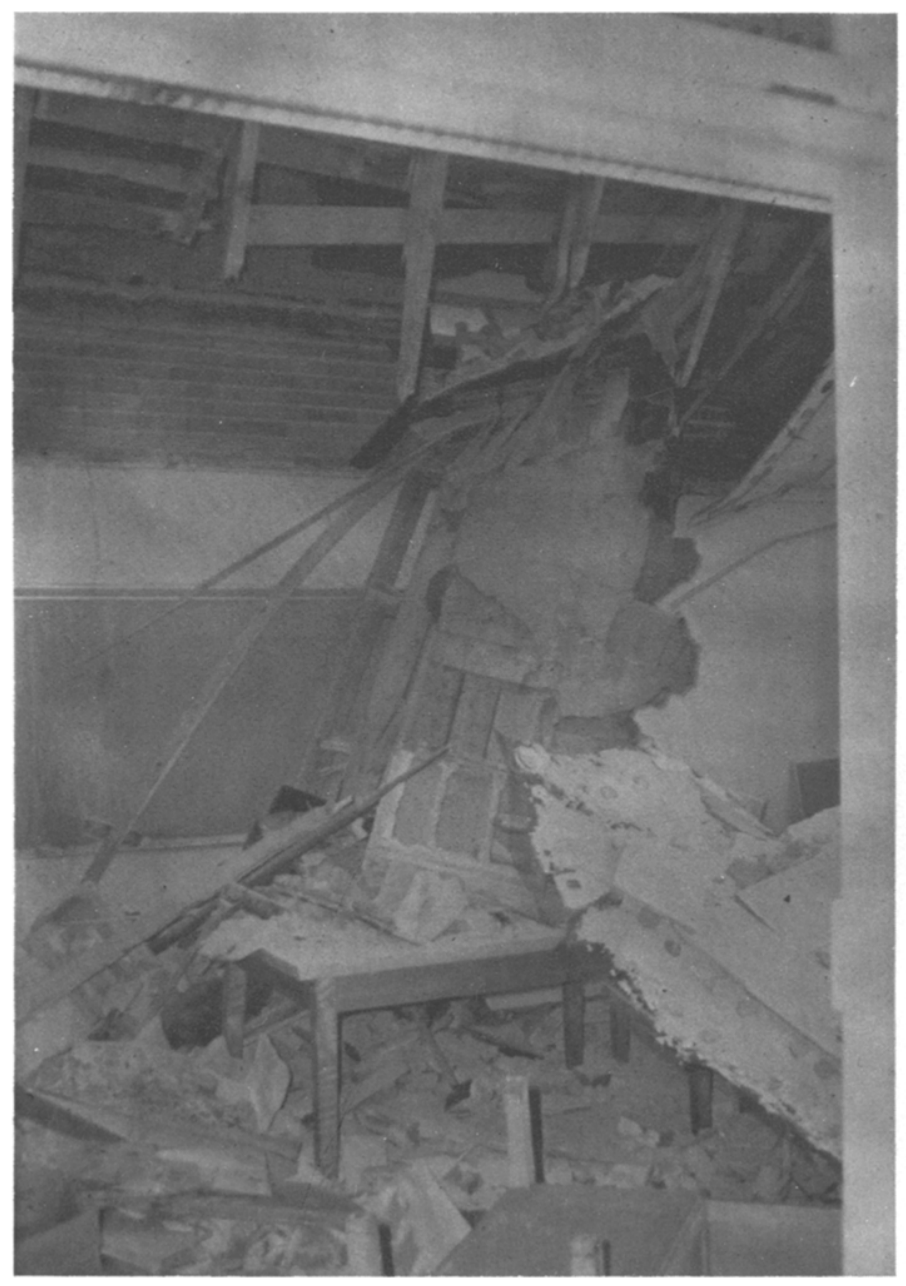

Fig. 7. Interior damage, Los Angeles High School.

The severity of ground shaking in Long Beach was considerably less than in San Fernando. The overall size as measured by magnitude of the two events was approximately the same, but there was no evidence of surface faulting or of disturbed ground at the school sites in Long Beach as in San Fernando. The faulting mechanism in Long Beach is believed to be primarily horizontal on a fault system roughly parallel to the San Andreas Fault. Considering the location of the epicenter at sea, the absence of surface faulting, and the probable length of faulting, it is likely that the main regions of seismic 


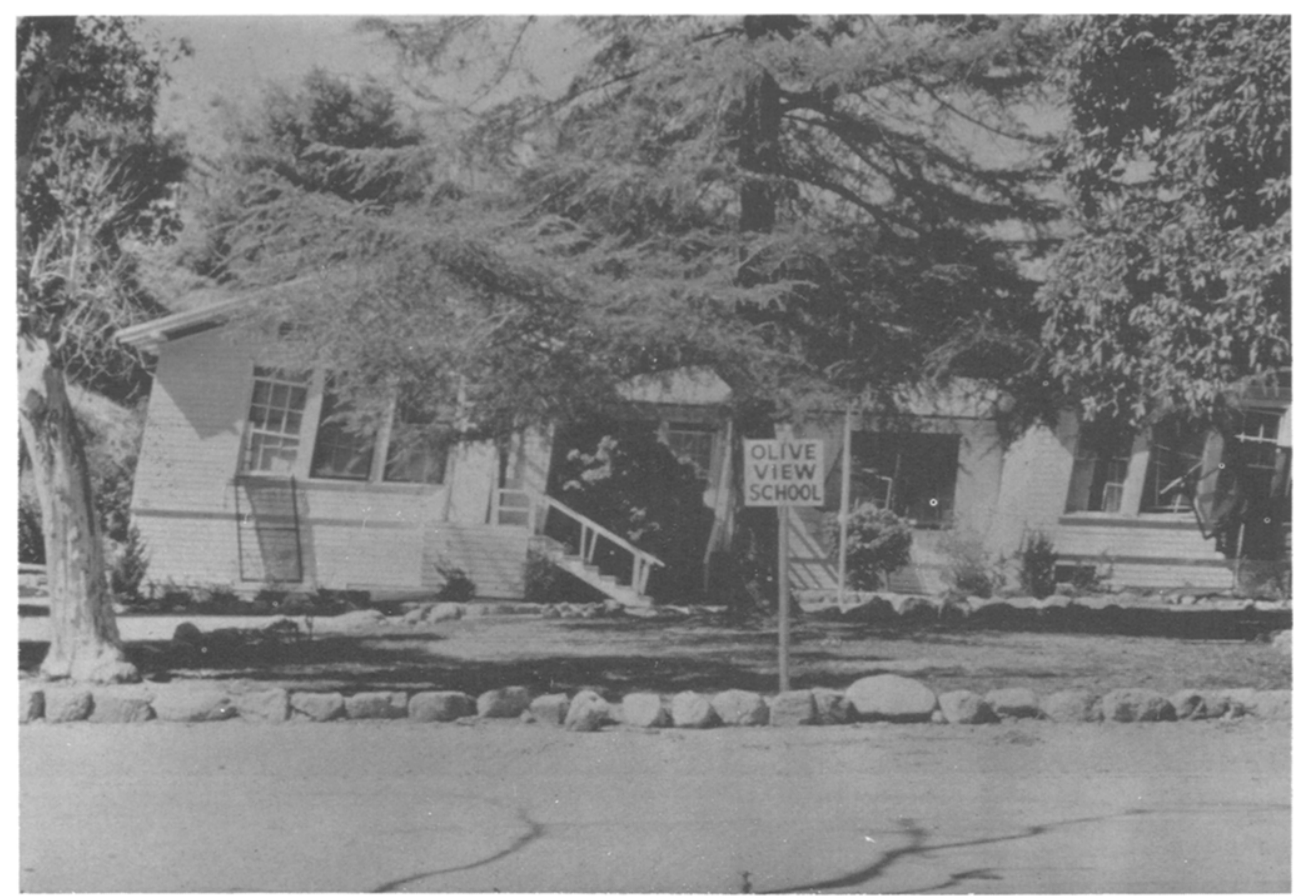

FIG. 8. Olive View Hospital School after earthquake.

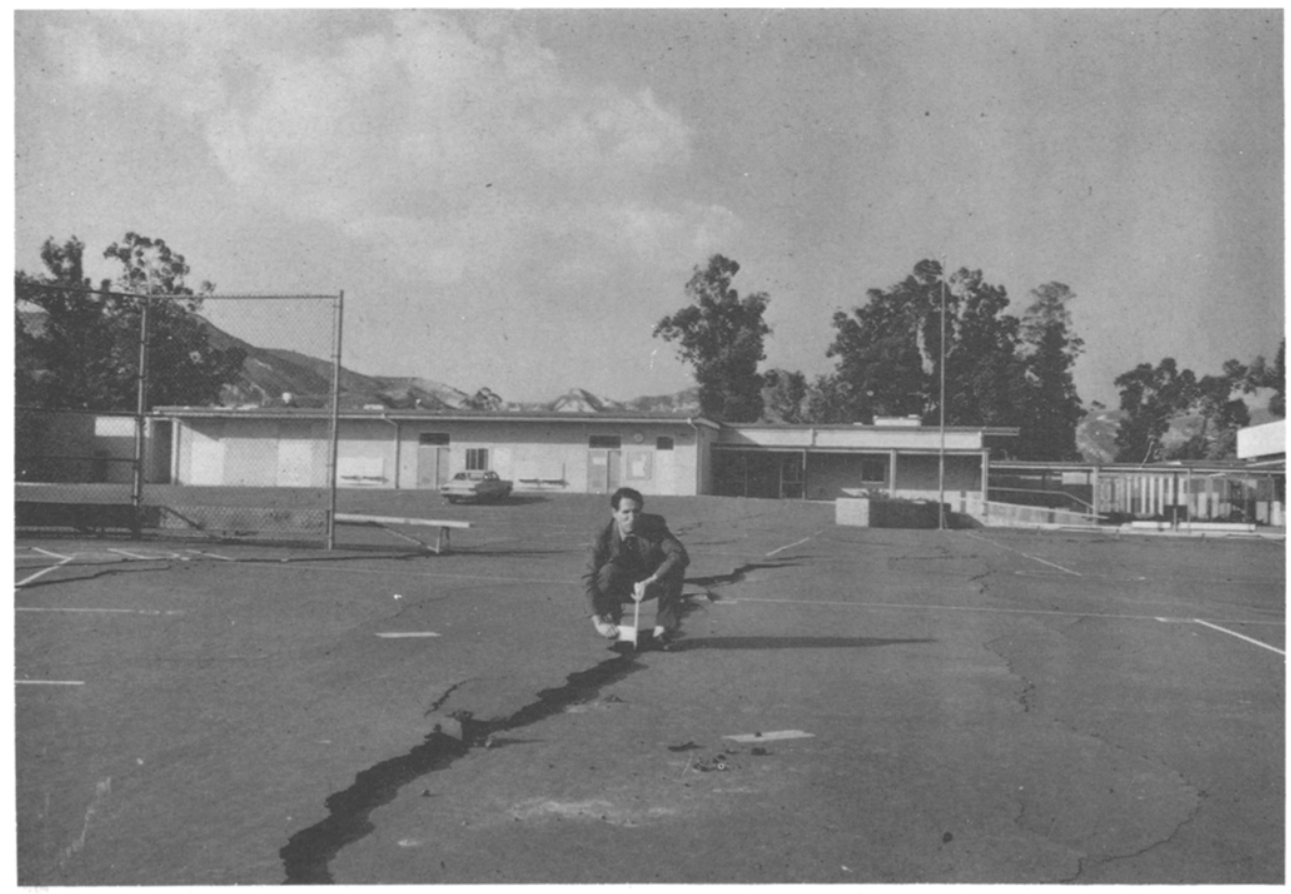

FIG. 9. Van Gogh Elementary School, showing cracks in playground. 


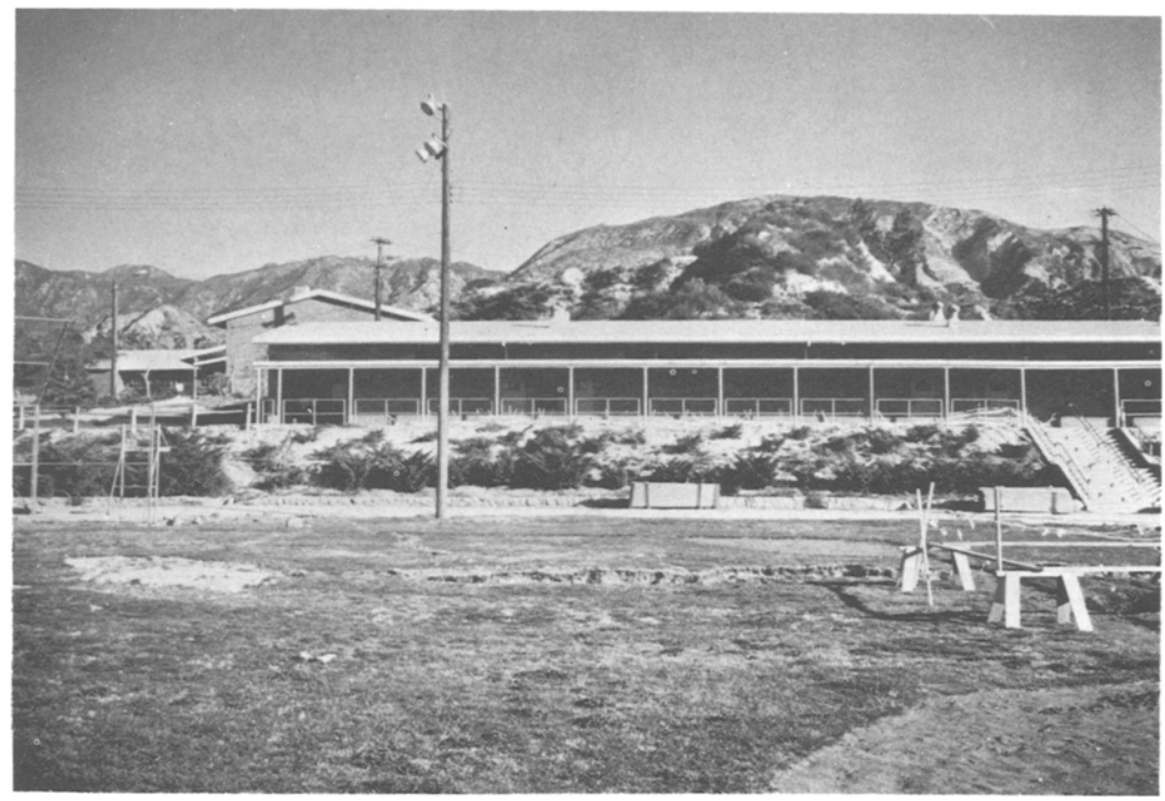

Fig. 10. School at Camp Karl Holton, showing vertical crack in playground.

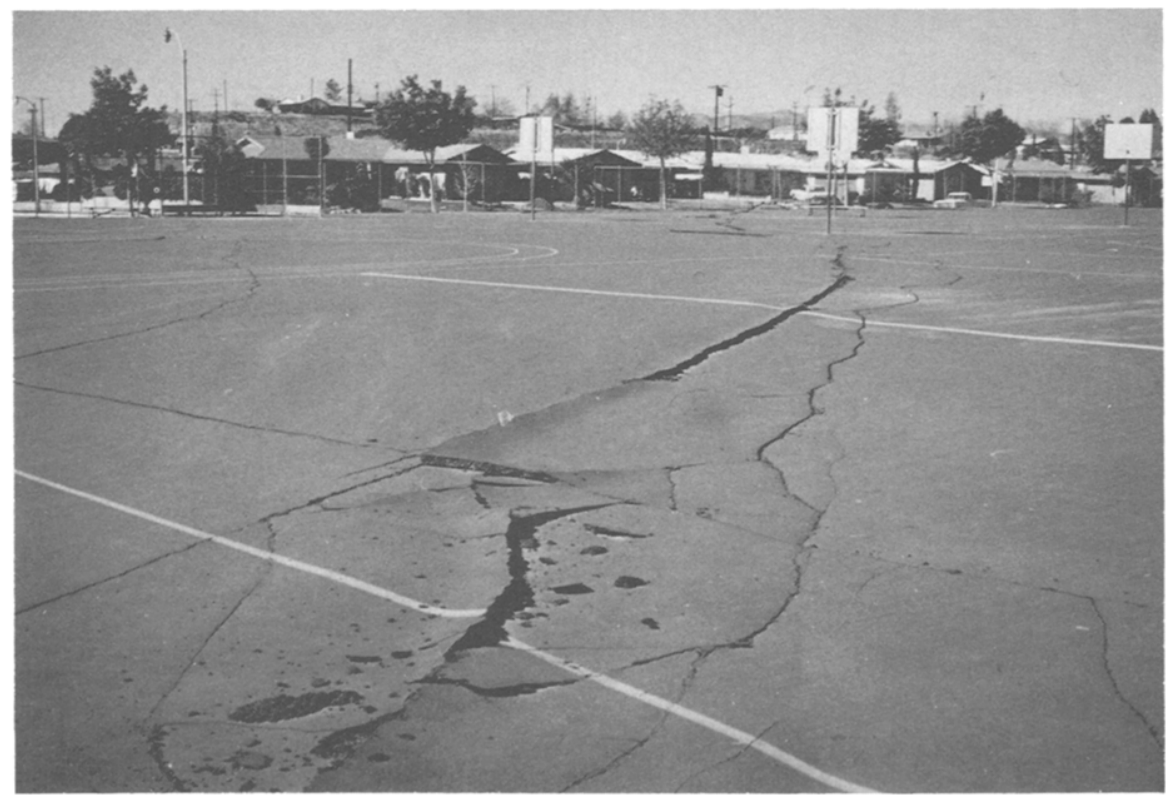

FiG. 11. Harding Street School, located in area of heavy ground disturbance (see Figure 4). 


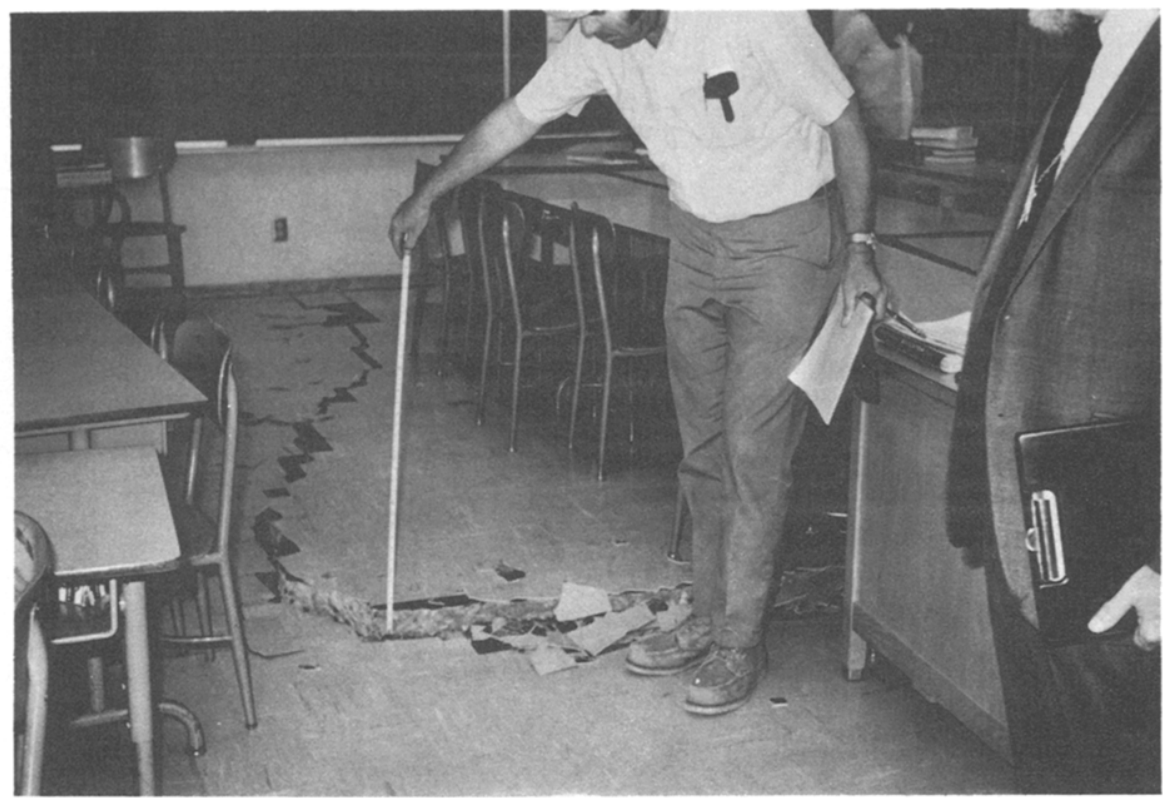

FIG. 12. Harding Street School, showing floor cracks inside classroom.

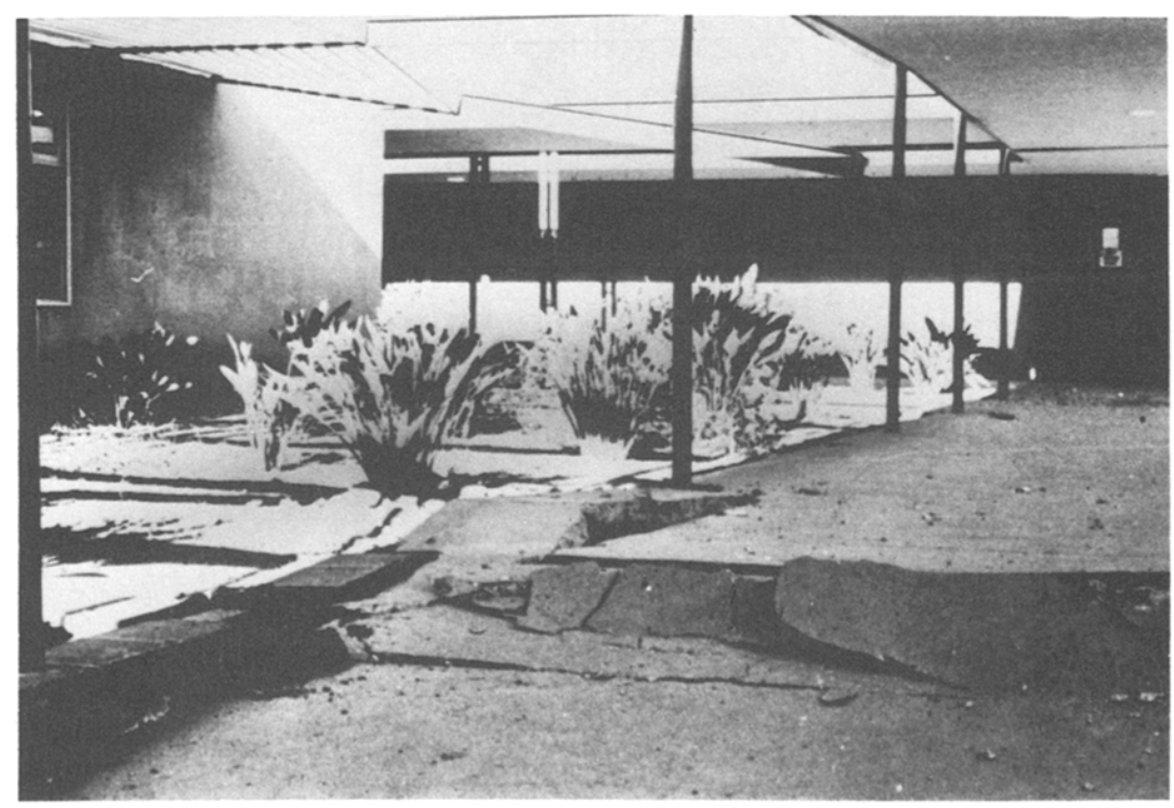

FIg. 13. Sylmar High School, arcade and walkway damage. 
energy release were farther from the school sites than in San Fernando. The maximum reported Modified Mercalli intensity in the Long Beach earthquake was IX (Neumann, 1935). Other authorities have doubted that the intensities exceeded VIII (Wood, 1933). The earthquake occurred at the very beginning of the strong-motion accelerograph program and produced the first accelerograms of strong ground motion obtained anywhere. The three accelerograms obtained from the earthquake included one from Long Beach itself, which, while in some respects incomplete, indicated clearly that the ground

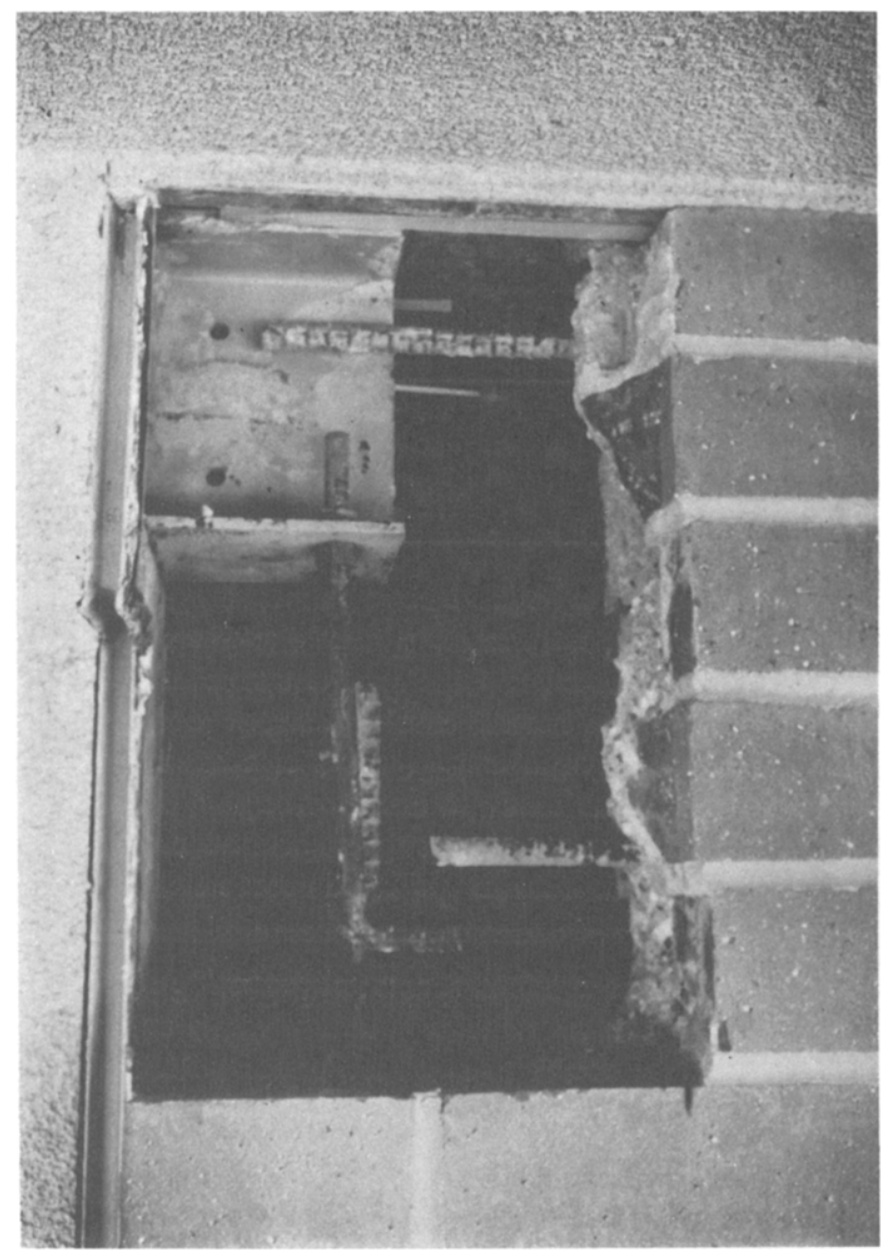

Fig. 14. Soledad Canyon Elementary School, unwelded reinforcing bar.

acceleration levels were of the order of $0.25 \mathrm{~g}$ (Neumann, 1935). As compared with Figure 5 , this is seen to be a level perhaps only one-half of that attained at a number of school sites during the San Fernando earthquake. All engineering reports of the Long Beach earthquake emphasize that the damage was mainly the consequence of weak structures rather than of unusually severe ground motion (Martel, 1936; Binder, 1952).

\section{EFFECTS ON TyPICAL SCHOOL STRUCTURES}

As a first example of the effects of the San Fernando earthquake on typical school 
structures, severe structural damage to a pre-Field Act school will be cited. Figure 6 shows a view of a portion of the Los Angeles High School main building which was constructed in 1917, well before the day of earthquake codes and inspections. The school is some 25 miles south of the epicenter, and it can be judged from ground accelerations measured approximately one-half mile away that the ground acceleration was of the order of $0.10 \mathrm{~g}$. It will be seen that substantial portions of the terra cotta and masonry parapets fell from the wall. Part of the debris buried a stairway which might have been serving as an emergency exit, and another portion fell through the roof of a lower wing into a classroom below, as shown in Figure 7. This is clearly a very hazardous situation which could have seriously injured students, had school been in session at the time of the earthquake. In this case, it was not economically feasible to repair and strengthen the building to current code requirements, and it was accordingly demolished. This is a

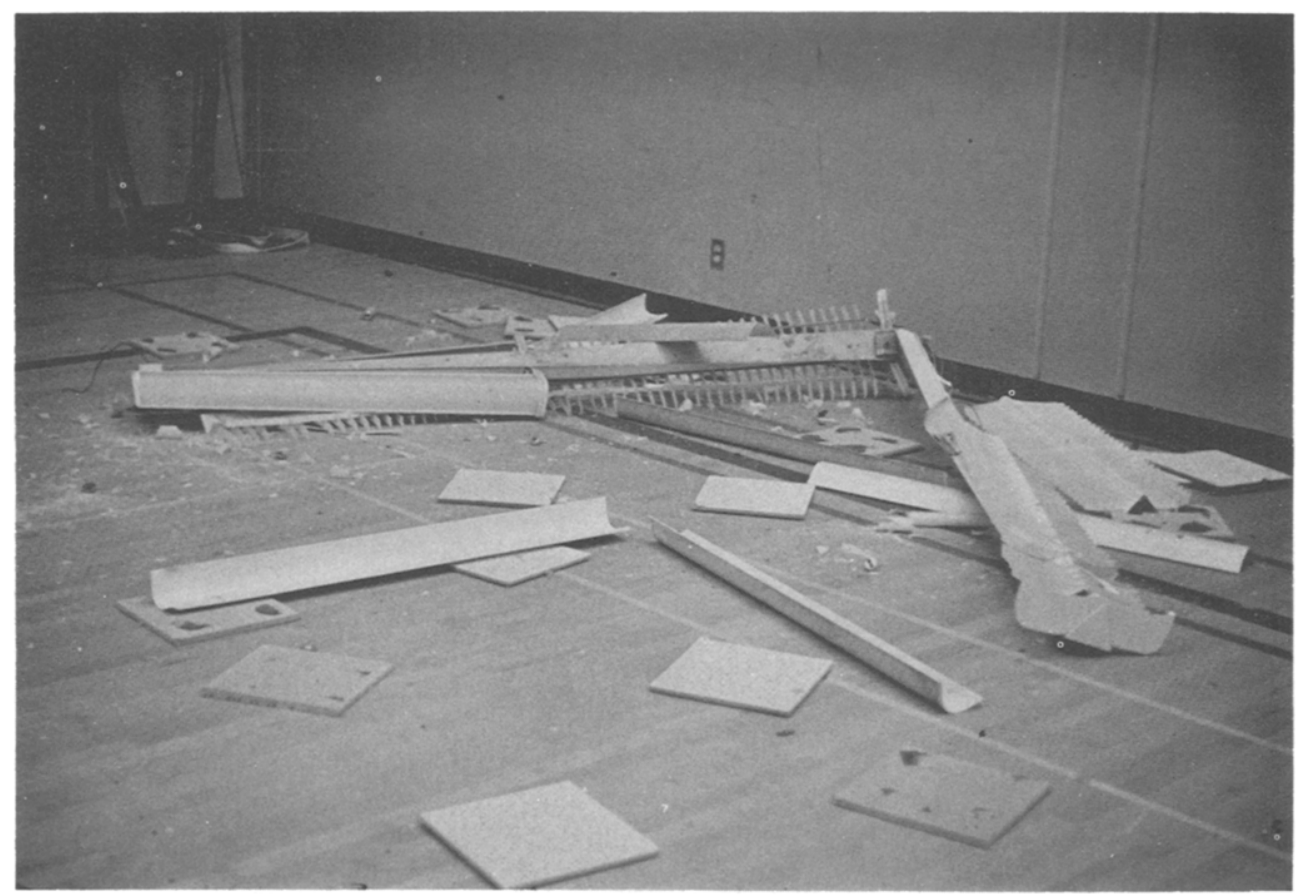

FIG. 15. Placerita Junior High School, failure of lighting fixtures.

good example of a school building which was well known to be substandard and a potential hazard, yet the social and economic pressures for its continued use were apparently irresistible.

The fate of a small school building on the Olive View Hospital site is of interest because of the widespread attention received by the collapse of two new hospital buildings there. Figure 8 shows the postearthquake appearance of the wood-frame school building, which was only several hundred feet from the collapsed hospital building. The building is typical of about 500 such school structures in use in the Los Angeles area at the time of the earthquake. Although the building was a total loss and was subsequently demolished, it is important to note that no hazardous collapse was involved and there would probably have been no serious injury to occupants.

A number of schools were located in regions of heavy ground disturbance and yet 
were able to survive with no hazardous structural damage. Figure 9 is a view of the Van Gogh Elementary School, about one-half mile from the Upper Van Norman Lake Reservoir in an area which had peak horizontal ground accelerations of the order of $0.40 \mathrm{~g}$. There were numerous severely damaged structures in the immediate vicinity of the school. Although there was structural damage to the foundation footings, no hazardous structural damage occurred to the building. Figure 10 shows a substantial vertical ground displacement running through the grounds of the school at Camp Karl

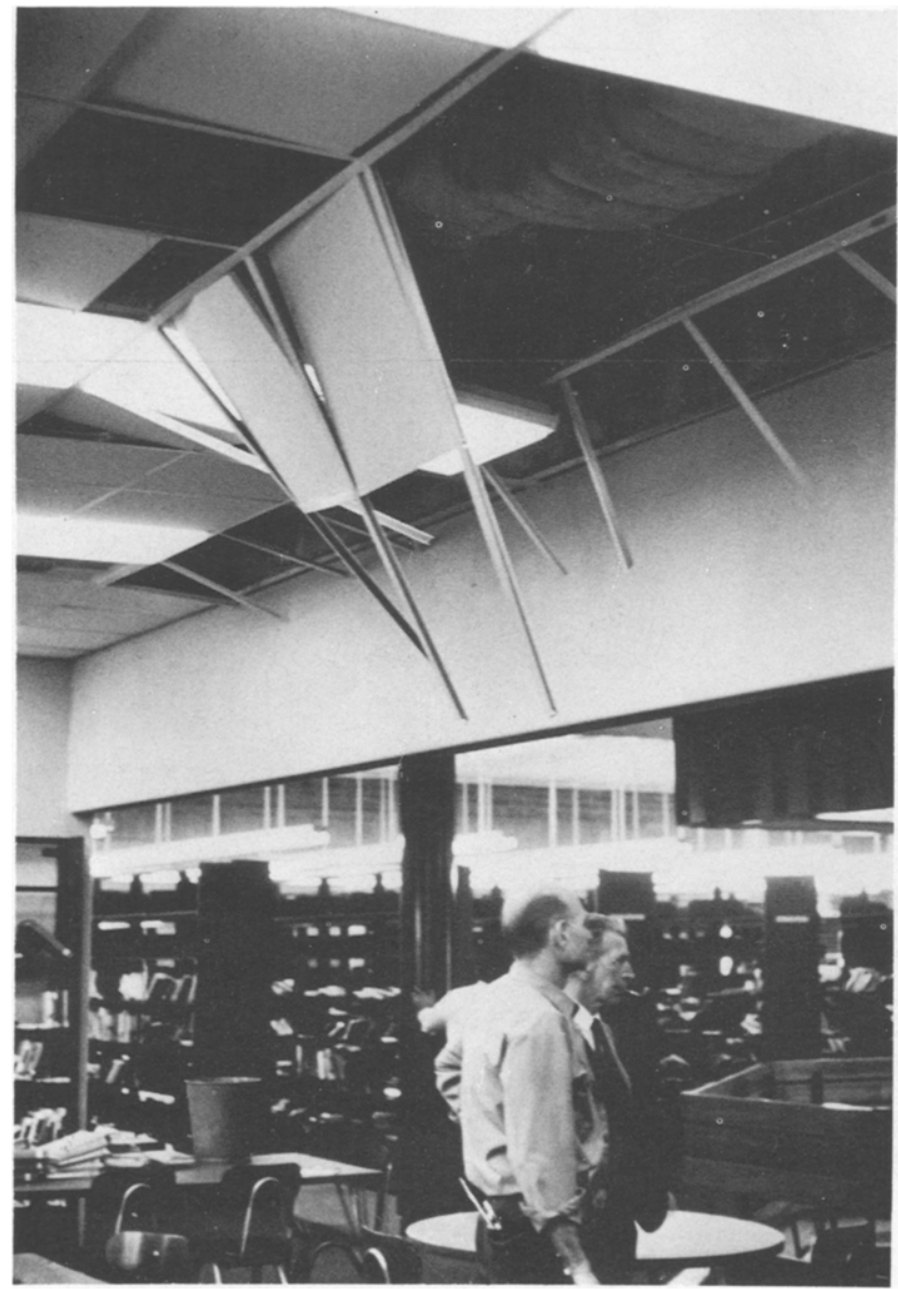

FIG. 16. Canyon High School, failure of suspended T-ceiling.

Holton, 3 miles from Pacoima Dam and $1 \frac{1}{2}$ miles from the main surface expression of the Tujunga Fault. Again an absence of hazardous structural damage to the school buildings is noted.

Another school in the immediate area of heavy ground disturbance is shown in Figure 11 , and Figure 12 shows the results inside a classroom. Although considerable repairs were required, no hazardous situation was involved. A final example of severe ground distortion is at the Sylmar High School in Figure 13, in which a considerable disruption of walkways, arcades, etc., occurred, again without hazardous structural damage. It is 


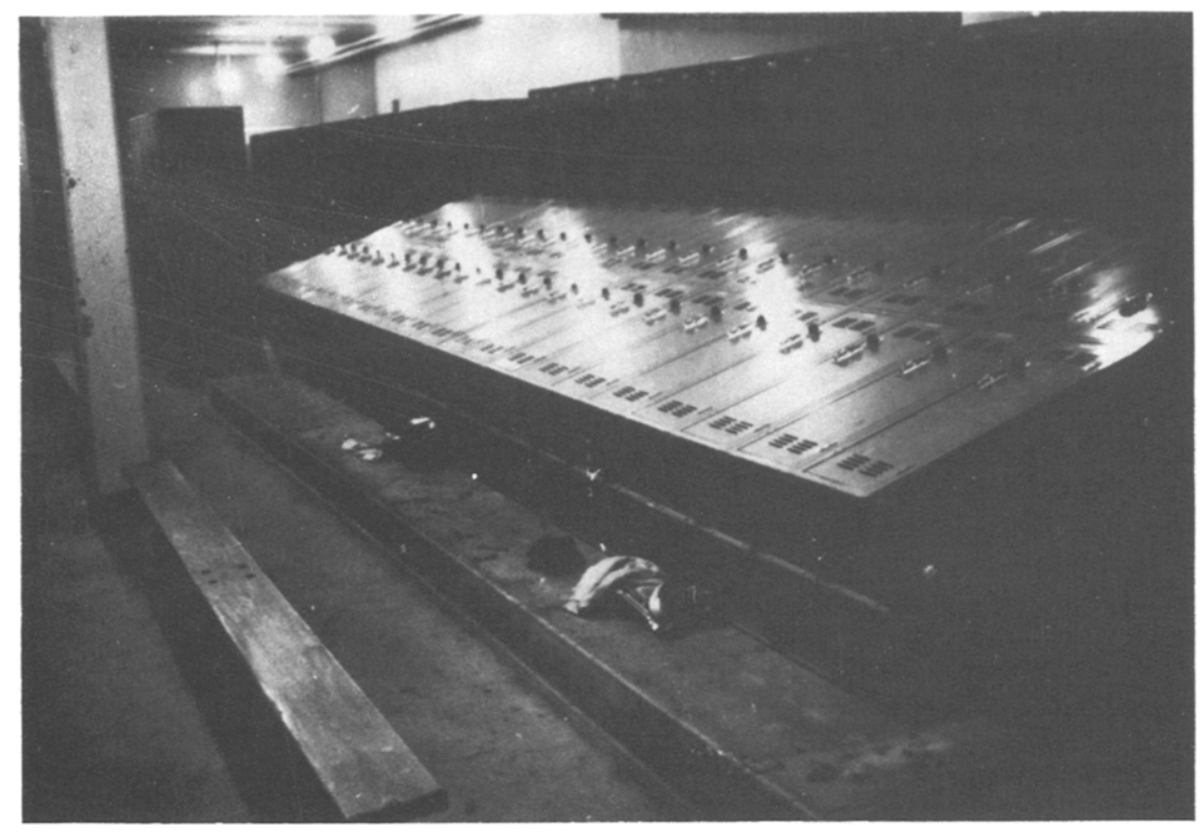

Fig. 17. Sylmar High School, toppling of lockers in gymnasium.

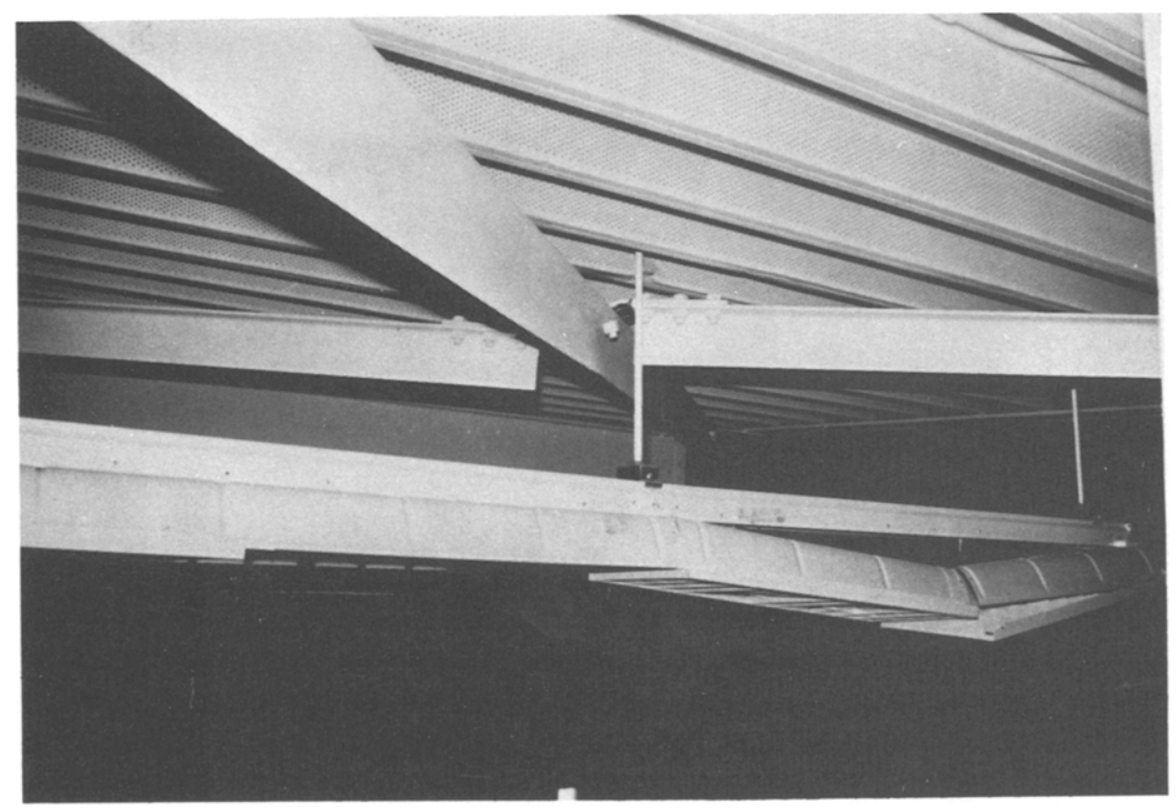

Fig. 18. Canyon High School, yielding of a steel roof member. 
evident that modern school structures of the above types can tolerate severe foundation distortions without dangerous collapse.

Interesting examples of minor damage directly attributable to construction and inspection defects occurred at the Soledad Canyon School. Figure 14 shows a reinforcing bar in a masonry wall which should have been welded to the steel I-beam. Such defects should be prevented by standard inspection techniques and simply point up the continuing necessity for vigilance in this respect.

The biggest hazards to life and limb in modern school structures were numerous failures of nonstructural elements. Typical examples are the overhead light fixtures of Figure 15, suspended T-ceilings of Figure 16, and unsecured equipment such as the lockers in Figure 17.

The absence of major structural damage in the modern school buildings throughout the epicentral region does not mean that very large structural forces were not involved or that excessive conservatism in the design had been used. Figure 18 shows a typical yielding response of a steel roof member showing that earthquake loads considerably in excess of ordinary design loads were encountered.

\section{Conclusions}

Considering that the severity of the ground motions involved in the San Fernando earthquake were probably close to the maximum values to be expected for an earthquake of even the largest size, the fact that the public school buildings constructed since 1933 could withstand these motions with an almost complete lack of hazardous structural damage is a remarkable tribute to the effectiveness of the methods used by the California State Office of Architecture and Construction to ensure school safety. Since the earthquake additional improvements have been made in the code procedures to avoid those deficiencies in nonstructural elements noted in the earthquake behavior. It is clear that in its present form the standard code does achieve an appropriate balance between economic construction and earthquake safety for the public schools in California.

\section{ACKNOWLEDGMENTS}

Appreciation is expressed to officials of the Los Angeles Unified School District for assistance with the school location map and for information on school damage. The project was made possible by a grant from the National Science Foundation. Support from the Earthquake Research Affiliates program of the California Institute of Technology is also gratefully acknowledged.

\section{REFERENCES}

Allen, C. R., G. R. Engen, T. C. Hanks, J. M. Nordquist, and W. R. Thatcher (1971). Main shock and larger aftershocks of the San Fernando Earthquake, February 9 through March 1, 1971, The San Fernando, California, Earthquake of February 9, 1971, U.S. Geol. Surv. Profess. Paper 733, U.S. Geological Survey, Washington, D.C.

Allen, C. R., T. C. Hanks, and J. H. Whitcomb (1974). Seismological studies and their tectonic implications, San Fernando Earthquake, Bulletin 196, California Division of Mines and Geology, (in press).

Binder, R. W. (1952). Engineering aspects of the 1933 Long Beach earthquake, Proc. Sym. Earthquake and Blast Effects on Structures, Earthquake Engineering Research Institute and University of California, Berkeley.

Bonilla, M. G., et al. (USGS staff) (1971). Surface faulting, The San Fernando, California, Earthquake of February 9, 1971, U.S. Geol. Surv. Profess. Paper 733, U.S. Geological Survey, Washington, D.C.

Hanks, T. C. (1974). The faulting mechanism of the San Fernando earthquake, J. Geophys. Res. 79, 1215-1229. 
Housner, G. W. (ed.) (1973). The Great Alaska Earthquake of 1964-Engineering, National Academy of Sciences, Washington, D.C.

Hudson, D. E. (1972). Strong motion seismology, Proc. Intern. Conf. Microzonation, Seattle.

Hudson, D. E. and W. K. Cloud (1973). Seismological background for engineering studies of the earthquake, The Great Alaska Earthquake of 1964-Engineering, National A.cademy of Sciences, Washington, D.C.

Hudson, D. E. and F. E. Udwadia (1973). Local distribution of strong earthquake ground motion, Proc. 5th World Conf. Earthquake Eng., Rome.

Jephcott, D. K. and D. E. Hudson (1974). The performance of public school plants during the San Fernando earthquake, Earthquake Engineering Research Laboratory, California Institute of Technology, Pasadena, (in press).

Lawson, A. C., (1908). The California earthquake of April 18, 1906, Carnegie Institution of Washington, Washington, D.C., (Reprinted 1969).

Martel, R. R. (1964). A report on earthquake damage to Type III buildings in Long Beach, Earthquake Investigations in the Western United States-1931-1964, D. S. Carder, Editor. Coast and Geodetic Survey, U.S. Department of Commerce, Publication 41-2, Washington, D.C.

Neumann, F. (1935). United States Earthquakes, 1933, Coast and Geodetic Survey, U.S. Department of Commerce, Washington, D.C.

Richter, C. F. (1958). Elementary Seismology, W. H. Freeman, San Francisco.

Scott, N. H. (1971). Preliminary report on felt area and intensity, The San Fernando, California, Earthquake of February 9, 1971, U.S. Geol. Surv. Profess. Paper 733, U.S. Geological Survey, Washington, D.C.

Trifunac, M. D. (1974). A three-dimensional dislocation model for the San Fernando, California, earthquake of February 9, 1971, Bull. Seism. Soc. Am. 64, 149-172.

Von Hake, C. A. and W. K. Cloud (1966). United States Earthquakes, 1964, Coast and Geodetic Survey, U.S. Department of Commerce, Washington, D.C.

Wood, H. O. (1933). The Long Beach Earthquake of March 10, 1933, Bull. Seism. Soc. Am., 23, 43-56.

\section{EARTHQUAKE ENGINEERING RESEARCH Laboratory \\ California Institute of Technology \\ Pasadena, California (D.E.H.)}

\author{
California State Office of Architecture \\ AND CONSTRUCTION \\ Los Angeles, California (D.K.J.)
}

Manuscript received May 16, 1974. 